\title{
Mosquito Diversity In Blok Ireng-Ireng And Ranu Darungan Area of Bromo Tengger Semeru National Park
}

\author{
Dwi Rahmawati", Nirmala Fitria Firdausi, Saiful Bahri \\ Biology Departement, Faculty Sains and Technology, Universitas Isalam Negeri Sunan Ampel \\ Surabaya \\ *email:dwirahmaa510@gmail.com
}

\begin{tabular}{|c|c|}
\hline Article Info & ABSTRACT \\
\hline & Bromo Tengger Sel \\
\hline $\begin{array}{l}\text { Key word: } \\
\text { Biodiversity }\end{array}$ & as life support, and c \\
\hline avito & important role in maintaining the balance of the ecosystem. \\
\hline Mosquito & Mosquitoes, which are ectoparasites can be vectors of disease \\
\hline Blok Ireng-ireng & in humans, this study was conducted to determine the level of \\
\hline Ranu Darungan & mosquitoes diversity and their distribution which allows the \\
\hline Art & $\begin{array}{l}\text { transmission of disease vectors in the area. The study was } \\
\text { conducted during January-February } 2021 \text { with the non- }\end{array}$ \\
\hline Received: $27 / 07 / 2021$ & probability sampling method, and accidental sampling. The \\
\hline Revised: $21 / 12 / 2021$ & results obtained were 19 mosquito species with a diversity index \\
\hline Accepted: 19/01/2022 & $\begin{array}{l}\text { calculation of } H^{\prime}(2.36) \text { for Ireng-ireng Block and } H^{\prime}(1.71) \text { for } \\
\text { Ranu Darungan which both fall into the medium category. }\end{array}$ \\
\hline
\end{tabular}

Copyright $(2022$ Author(s). All Right Reserved

\section{Introduction}

Bromo Tengger Semeru National Park is one of the National Parks that has the characteristics of a Tropical Rain Forest type and located in the Tengger Mountains, precisely in Lumajang Regency, East Java. The Bromo Tengger Semeru National Park area has an area of 50,276.20 hectares consisting of 50,265.95 hectares of land area and 10.25 hectares of water area (Sawitri \& Takandjandji, 2019; Susanto \& Bahri, 2021). The Blok Ireng-ireng and Ranu Darungan are part of the Bromo Tengger Semeru National Park area with different environmental conditions. The Ireng-ireng block has a land area of \pm 485 ha with diverse vegetation densities and there is a river that is used as a water source by the surrounding community. Apart from that, the Blok Irengireng is an alternative route that connects Malang Regency with Lumajang Regency so that this area is bustling with human activities (Millah, 2020). Meanwhile, Ranu Darungan is an area in the form of Ranu or a lake with an area of 0.25 hectares surrounded by forests and cliffs at an altitude of 830 meters above sea level in the Bromo Tengger Semeru National Park area (Balai Besar Taman Nasional Bromo, 2015).

Diversity or Biodiversity is one of the terms used to express the richness and diversity ranging from genetic variation and species variation, in an ecosystem. Biodiversity includes the diversity of animals and plants, as well as microorganisms stored in nature (Permana, 2015). Indonesia has a fairly large diversity of insect species, one of which is the mosquito which is an invertebrate animal from the Insecta or Insect Class, Order Diptera, with Sub Order Nematocera (having approximately 35 families).

Mosquitoes are one type of ectoparasite insect that can be a vector of 
disease in humans through their bites. Each type of mosquito has different characteristics apart from morphological characteristics, also in feeding behavior (antropophilic or zoophilic), blood-sucking habit, habitat / place of life both in the larval and adult stages. The abundance and survival of mosquitoes closely related to the availability of breeding sites so that the types and numbers found are different in each breeding place (Ningsih, 2016).

Research on mosquitoes conducted in Baluran National Park by (Purwatiningsih, 2021), obtained seven types of mosquitoes from the Aedes and Culex genera with a diversity index value $(1,21)$ in the medium category. Where as the research on mosquitoes in the Bromo Tengger Semeru National Park area has not developed well so this research was conducted to determine the diversity of mosquitoes in the Ireng-ireng and Ranu Darungan Block areas which are part of the Bromo Tengger Semeru National Park area so that data on the diversity of mosquitoes and information on mosquito breeding sites around Bromo Tengger Semeru National Park.

\section{Materials and Methods}

This research was conducted on January-February 2021 in the Blok Irengireng and Ranu Darungan areas of Bromo Tengger Semeru National Park and the surrounding residential areas. The preservation and identification of mosquitoes were carried out at the Integrated Laboratory of UIN Sunan Ampel Surabaya.

The collection stage was carried out using a non-probability sampling method by placing ovitraps at five points in each area with a distance of 15-20 meters, taking into account the preferred habitat or environment as a breeding ground. The sampling process was accompanied by observations and measurements of ecological parameters including temperature, water $\mathrm{pH}$, water turbidity and dissolved oxygen (DO) levels. Furthermore, the sample of mosquito larvae obtained was preserved using a semi- permanent method with glycerin and covered with cover glass.

The identification process was carried out using a stereo microscope with the book Illustrated Key to Mosquitoes Vietnam by Stojanovich, Chester. J. 1996, A Checklist of the Mosquitoes in Indonesia by Connor, C. T., \& Sova, T., 1981 and on the mosquito taxonomic inventory. The identified larvae samples were then tabulated and analyzed using the Shannon-Wienar diversity index based on (Ningsih, 2016; Fatiqin, 2019; Mujijah et al., 2019) with the following formula.

Diversity index:

Note:

$$
\begin{gathered}
\mathrm{H}^{\prime}=-\sum \mathrm{pi} \ln p i \\
\mathrm{H}^{\prime}=-\sum\left\{\left(\frac{n i}{n}\right) \ln \left(\frac{n i}{n}\right)\right\}
\end{gathered}
$$

$\mathrm{H}^{\prime}$ : Diversity index

ni : Number of individuals

$\mathrm{n}$ : Total number of individuals

$\Sigma$ : Shows the total count

Species evenness $(E)$ :

Note:

$$
\mathrm{E}=\frac{H \prime}{\ln S}
$$

$\mathrm{S}^{\prime}$ : Spesies count

Frequency of presence:

$\mathrm{F}=\frac{\text { jumlah plot tempat keldiran suatu spesies yang ditemukan }}{\text { jumlah total plot tempat yang diamati }} \times 100 \%$

\section{Dominance:}

$$
\text { Ds }=\sum(\mathbf{P i})^{2}, \operatorname{dimana} \mathbf{P i}=\mathbf{n i} / \mathbf{N}
$$

\section{Results and Discussion}

Identification of mosquito larvae from preservation obtained from Blok Ireng-ireng and Ranu Darungan obtained 19 species from 4 different genera of mosquitoes (Table $1)$.

The distribution of species in the study area obtained different results, it was influenced by the characteristics of the environment and aquatic habitats in the form of biotic and abiotic factors. There were three species of mosquitoes that have the highest frequency of presence and spread throughout the study area, they are Aedes saxicola, Aedes chrysolineatus and Aedes albopictus. The three mosquitoes are 
exophilic mosquitoes that are easily found outside the house, and occupy natural and artificial habitats around humans or far from humans (Sabir et al., 2017).

Table 1. Species of mosquitoes found

\begin{tabular}{ccc}
\hline Spesies & \multicolumn{2}{c}{ Area } \\
\cline { 2 - 3 } & $\begin{array}{c}\text { Blok } \\
\text { Ireng- } \\
\text { ireng }\end{array}$ & Darungan \\
\hline Ae. albopictus & 17 & 6 \\
Ae. pseudoalbopictus & - & 14 \\
Ae. aegypti & 19 & - \\
Ae. albolineatus & 6 & 8 \\
Ae.Niveus & 4 & - \\
Ae. chrysolineatus & 10 & 29 \\
Ae. saxicola & 15 & 3 \\
Ae. formosensis & 6 & - \\
Ae. assamensis & 13 & - \\
Ae. impremens & 5 & - \\
Ae. alboscutellatus & 3 & - \\
Ae. iyengari & - & 7 \\
Cx. sitiens & - & - \\
Cx. mimeticus & 4 & - \\
Cx. pseudovishnui & 3 & - \\
Cx. Fragilis & 35 & - \\
Cx. quinquefasciatus & 6 & - \\
Tx. Albipes & - & - \\
Trp. Proximus & - & 23 \\
\hline
\end{tabular}

The presence of the most species by the Aedes genus is then followed by the Culex genus, the Aedes mosquito has the type of container breeding in breeding and likes clean/clear water environmental conditions. So it is often found in bathtubs and indoor areas such as puddles in gallons of water, water reservoirs and so on (Pramadani et al., 2020). The Aedes genus which has good adaptability makes the Aedes genus easy to find in several conditions such as densely populated settlements, plantation land and water sources the Aedes mosquitoes a good opportunity to breed.

The Culex genus which occupies the second high diversity value after the Aedes genus, with an almost evenly distributed species distribution is known to have environmental suitability both indoors and outdoors. By occupying puddles and small rivers that are clear to slums, making this genus mosquito easy to grow found in the research area. A suitable habitat makes the abundance value of a species high because it supports Culex mosquitoes to breed (Tallan \& Mau, 2016). The Aedes and Culex genera in several species are known to be vectors of filariasis, dengue and malaria, providing the possibility of disease transmission in the environment, the presence and spread of disease vectors influenced by environmental and climatic factors, as well as affecting the growth and reproduction of mosquitoes (Pramadani et al., 2020).

The results of data analysis based on the Shannon-Wiener index through the identification of mosquito larvae species obtained the value of diversity, evenness index between species, dominance in the distribution of species in each area, which are presented in table 2 .

\begin{tabular}{ccc} 
Table 2. & $\begin{array}{c}\text { Shannon-Wiener } \\
\text { Results }\end{array}$ & Analysis \\
& \multicolumn{2}{c}{ Kawasan } \\
\cline { 2 - 3 } Indeks & $\begin{array}{c}\text { Blok } \\
\text { Ireng-ireng }\end{array}$ & Darungan \\
\hline Diversity (H') & 2,36 & 1,71 \\
Evenness (E) & 0.89 & 0,88 \\
Dominance (D) & 0,07 & 0,06 \\
\hline
\end{tabular}

The diversity index in the Ireng-ireng Block area H' (2.36) belongs to the medium category, this is because the Ireng-ireng Block area has a complete and wellmaintained vegetation structure that allows for an abundance of species and has a high diversity value. The vegetation in question is a forest support structure in the form of density and diversity of forage plants contained in the forest so that fauna can live and reproduce and get food so that the diversity of forest flora and fauna can develop and continue to increase (Azi et al., 2019).

The Ireng-ireng Block area has the highest evenness index value E (0.89), this evenness indicates that species domination is getting less and less. Because the higher the evenness index value obtained, the distribution of individuals in each species is more evenly distributed. This is indicated by the presence of only one species that 
dominates in terms of the number of individuals (n), namely Culex fragilis. The Culex fragilis mosquito that dominates in the Blok Ireng-ireng area shows that this mosquito is exophilic although it is often referred to as a house mosquito, the cool and humid conditions with lots of trees and shrubs make it a comfortable resting place and preferred by Culex fragilis mosquitoes in the adult phase.

The diversity index in Ranu Darungan is lower than the diversity index in the Irengireng Block area, with $\mathrm{H}^{\prime}(1.71)$, the low value of the diversity index was due to the narrow sampling area and the dense and dense forest vegetation, making it difficult to find breeding grounds for mosquito larvae. The condition of the forest that is far from water sources with a density of large trees and shrubs makes the area shady so that little rainwater enters and is accommodated between tree holes, leaf litter, and puddles in soil holes. Found traces of wild boar, deer and other animals provide the possibility that puddles The water in the forest is used as a source of drinking water these animals before mosquitoes make them as miss place.

The results of the calculation of the evenness value in the Ranu Darungan obtained E (0.88) with the dominant species, namely Triptoides proximus. The Triptoides proximus mosquito that dominates in this area, it shows that in this area there are still protected and abundant bamboo trees, because the main habitat of this mosquito is in bamboo trees. In the Ranu area, there are no mosquito larvae that breed in Ranu waters due to large number of fauna or other animals that live in Ranu waters, such as various types of fish, frogs and snails which are estimated to be one of the predators for mosquito larvae.

The high and low value of the evenness index of a species is related to the bionomic of the mosquito species. The more evenly the species in an area, the better the quality of the environment to survive. The evenness index value has a negative correlation with the dominance value of species in an area, namely the evenness index value is inversely proportional to the dominance value (Amlarrasit et al, 2018). The value of species dominance in an area shows the actual population density. This dominance value is used as an approximate index in the analysis of transmission and distribution of disease vectors carried by mosquitoes.

The value of the highest frequency of species presence includes species, namely Aedes saxicola, Aedes chrysolineatus and Aedes albopictus. The difference in the value of the frequency of presence of each species occurs because the presence of biotic and abiotic factors breeding places, frequency high species presence can occur because the two areas study had environmental conditions suitable for the three species. Aedes saxicola, Aedes chrysolineatus and Aedes albopictus are mosquitoes exophilic which is easily found outside the home, and occupies natural or artificial habitats around humans or far from humans (Sabir et al., 2017). Shady environmental conditions and little sun exposure is very favored by these mosquitoes, so that these mosquitoes like breeding places such as gaps rocks, used bottles, leaf axils, clay pots, leaf hollows bananas, all of which can be found in the two research areas in Bromo Tengger Semeru National Park.

Environmental factors have a very large influence on the growth, development and distribution of mosquitoes, especially in species known as vectors of a disease. The balance of the mosquito population can be controlled by maintaining the balance of the existing ecosystem (Mahdalena et al., 2015). Indicators in the form of recorded temperatures are in the range of $18-25^{\circ} \mathrm{C}$, the temperature is influenced by the high plains of the research area and the current season, namely the rainy season. The average temperature used as a breeding ground for mosquito larvae is between $25-27^{\circ} \mathrm{C}$, the temperature of an area has an influence on the metabolism of the mosquito body because mosquitoes are cold-blooded animals and the high and low water temperatures are caused by the intensity of 
sunlight in the area. Mosquitoes cannot live in the environment which has a temperature of $<10^{\circ} \mathrm{C}$ and $>40^{\circ} \mathrm{C}$, so that if there is a change in extreme temperatures and reach these temperature degrees, growth mosquitoes will stop (Zaid \& Windraswara, 2017).

The $\mathrm{pH}$ value of the water in the mosquito larvae habitat has an important role in knowing the waters are alkaline, acidic or neutral, besides that the $\mathrm{pH}$ value is related to the amount of oxygen (DO) available in these waters, namely the lower the $\mathrm{pH}$ (acid) value, the lower the $\mathrm{pH}$ value. Dissolved oxygen levels are also getting less this is what causes the death of organisms (Mahdalena et al., 2015). The optimum $\mathrm{pH}$ value where the larvae develop is 7 and mosquito larvae can die if the $\mathrm{pH}$ is 3 (acidic) or 12 (alkaline), this value is not much different from the recorded $\mathrm{pH}$ value, which is in the range of 5.8-8.3. Each species of mosquito larvae has its own aquatic habitat, but in general aquatic biota prefer water conditions that have a $\mathrm{pH}$ value of 78.5 because this value is a value that is quite ideal for a living and developing biota (Amlarrasit et al, 2018).

The value of dissolved oxygen (DO) is influenced by the $\mathrm{pH}$ value of the waters and the presence of vegetation in the waters such as the presence of aquatic plants. the higher the vegetation, the higher the value of dissolved oxygen levels. Dissolved oxygen levels in mosquito larvae habitats were recorded between 1.3-5.2 $\mathrm{mg} / \mathrm{l}$, this value was stated to be quite stable and good for the growth and development of mosquito larvae in several habitats that had values $>3 \mathrm{mg} / \mathrm{l}$, this is as shown stated by (Ernamaiyanti \& Abidin, 2010) namely the dissolved oxygen level in good breeding mosquito larvae is that which has a value of $>3 \mathrm{mg} / \mathrm{l}$.

In addition to abiotic factors, biotic factors in a habitat also have an influence on the growth and development of a species. The presence of plants around the breeding of mosquito larvae affects the oxygen levels available in these waters. as well as functioning as a shelter from predators, protecting from the intensity of sunlight that is too extreme which can increase the temperature of the waters and as a source of food (Mahdalena et al., 2015).

\section{Conclusion}

The results of the research carried out can be concluded that the diversity of mosquitoes in the Ireng-ireng Block and Ranu Darungan areas is classified as moderate, the evenness value is high or evenly distributed with low species dominance.

\section{References}

Amlarrasit., Wijaya, M, A., Fatiqin, A (2018) Faktor Fisik dan Biologi yang Mempengaruhi Kepadatan Larva Anopheles di Kelurahan Kemelak. Prosiding Seminar nasional Sains dan Teknologi Terapan, 1(1). http://semnas.radenfatah.ac.id/view/8

Azi, H. D., Bintoro, A., \& Duryat. (2019). Faktor-Faktor Penentu Perubahan Kondisi Keanekaragaman Flora dan Fauna di Sub-Sub DAS Khilau, Sub DAS Bulog, DAS Sekampung. Jurnal Sylvia Lestari, 7(2). https://jurnal.fp.unila.ac.id/view/2993

Balai Besar Taman Nasional Bromo. (2015). Informasi Taman Nasional Bromo Tengger Semeru (TNBTS). Balai Besar Taman Nasional Bromo Tengger Semeru.

Ernamaiyanti, K. A., \& Abidin, Z. (2010). Faktor-Faktor Ekologis Habitat Larva Nyamuk AnopHeles di Desa Muara Kelantan Kecamatan Sungai Mandau Kabupaten Siak Provinsi Riau Tahun 2009. Journal of Enviromental Science, https://jil.ejournal.unri.ac.id/337/331

Fatiqin, A. (2019). Plankton Biodiversity in The Burai River of Ogan Ilir District, Sumatera Selatan. Biota, 12(1), 14-21. doi.10.20414/jb.v12i1.148

Mahdalena, V., Hapsari, N. S., \& Tanwirotun, N. (2015). Ekologi Habitat Perkembangbiakan Anopheles spp. di Desa Simpang Empat, 
Kecamatan Lengkiti, Ogan Komering Ulu, Sumatera Selatan. Jurnal Kesehatan, 14(4), 342-349. doi.10.22435/jek.v14i4.4713.342-349

Millah, N. (2020). Diversitas Dan Peranan Ekologi Kupu-Kupu (Rhopalocera) Di Area Blok Ireng-Ireng Kawasan Taman Nasional Bromo Tengger Semeru. University Islam Negeri Sunan Ampel Surabaya. http://digilib.uinsby.ac.id/id/eprint/42 958

Mujijah, Suyamto, Rasdianah Aziz, I., Parwito, \& Fatiqin, A. (2019). The Richness and Diversity of Plant Pollinator (Ordo: Lepidoptera) in Cigeulis District, Banten, Indonesia. Journal of Physics: Conference Series, 1175(1). doi.10.1088/17426596/1175/1/012008

Ningsih, W. F. (2016). Keanekaragaman Phytothelmata dan Larva Nyamuk yang Mendiaminya pada Habibat yang Berbeda di Desa Taman Sari, Kecamatan Gedong Tanaan, Kabupaten Pesawaran. Universitas Lampung.

Permana, S. R. (2015). Keanekaragaman Serangga Tanah di Cagar Alam Manggis Gadungan dan Perkebunan Kopi Mangli Kecamatan Puncu Kabupaten Kediri. UIN Maulana Malik Ibrahim. http://etheses.uinmalang.ac.id/id/eprint/3160

Pramadani, A., Kesumawati, U., \& Satrija, F. (2020). Habitat Aedes Aegypti dan Aedes Albopictus sebagai Vektor Potensial Demam Berdarah Dengue di
Kecamatan Ranomeeto Barat, Provinsi Sulawesi Tenggara. Jurnal Aspirator. Jurnal Aspirator, 12(2), 123-136. doi.10.22435/asp.v12i2.3269

Sabir, M., Annawaty, \& Fahri. (2017). Inventarisasi Jenis-Jenis Nyamuk di Desa Alindau, Donggala, Sulawesi Tengah. Journal of Science and Technology. Journal of Science and Technology, 6(3), 263-269. http://jurnal.untad.ac.id/view/9200

Susanto, M. A. D., \& Bahri, S. (2021). Diversity and Abundance Dragonflies (Odonata) at Mount Sigogor Nature Reserve Area, Ponorogo Regency, East Java, Indonesia. Jurnal Biota, $7(2)$, 101-108. doi.10.19109/biota.v7i2.8160

Tallan, M. M., \& Mau, F. (2016). Karakteristik Habitat Perkembangbiakan Vector Filariasis Di Kecamatan Kodi Balaghar Kabupater Sumba Barat Daya. Aspirator. Aspirator, 8(2), 55-56. doi.10.22435/aspirator.v8i2.4243.5562

Zaid, I. H., \& Windraswara, R. (2017). Lingkungan Tempat Perindukan Nyamuk Culex quiquefasciatus di sekitar Rumah Penderita Filariasis. Journal of public Health Research and Development. Journal of Public Health Research and Development, 1(2). https://journal.unnes.ac.id/php/higeia/ article/view/14148 